\title{
'Accepting the unacceptable': The Clash between Faith and Reason in New Pentecostal Churches in Zimbabwe
}

\author{
Joyline Gwara \\ ORCID iD: https://orcid.org/0000-0003-2245-1171 \\ Francis Machingura \\ ORCID iD: https://orcid.org/0000-0002-5161-5369
}

\begin{abstract}
Religion is the most interesting and ironical ideology that the world has ever experienced. Religions tend to evoke emotions that are protected from criticism, both from within and without. Africa has been marred with religious and cultural pluralism, with African Traditional Religion, Judaism, Christianity and Islam as its main traditions. Thus, the immediate experience of Africans is a mixture of a traditional, political, religious and cultural worldviews. The current situation in new Pentecostal movements in Zimbabwe is the flourishing numbers of prophetic Pentecostal movements that claim to solve African problems. What is ironic is the pace at which founders of these Pentecostal movements become wealthy, whilst their members continue to wallow in poverty, yet still hope for a holistic breakthrough as preached by the clergy. Is it not the gullible clergy who have realized that wealth quickly comes with the founding of a Church? Is it not the gullible followers who will survive the economic and religious abuses? Why is reason condemned in the 'faith' paradigm? In most cases, it is against this backdrop that we call for an analysis of issues to do with faith and reason in the face of religious pluralism and gullibility.
\end{abstract}

Keywords: faith, reason, religion, religious experiences 


\section{Introduction}

Religion is one of the most robust, greatly felt, and authoritative forces in human communities. It is responsible for shaping up inter/intra-connection between peoples or groups; guiding their families, communities, economics, and political life. This being the case, religion becomes a remarkable aspect of social life. As John Mbiti observes, 'Africans are notoriously religious' (Mbiti 1969). There is no doubt that religion is very significant for the lives of African people. It therefore follows that those religious values, places, beliefs and practices influence people's actions and their religious experiences that aid them in life. Though religion plays such a pivotal role in social life, it is one of the most pervasive phenomena of human life and culture in every lifetime. However, religion is taken for granted by many people without seriously questioning it.

With the rise of New Pentecostal Churches in Zimbabwe, religion, and in this case Christianity, has assumed a different meaning from what it used to be in the medieval period. Christianity in Zimbabwe is now characterized by prophets who predict people's fortunes; hence the so-called 'gospel of prosperity'. Charismatic leaders of these Churches have contextualized the gospel to fulfil the fantasies of their followers by performing all sorts of controversial miracles (miracle babies, miracle monies characterised by gold nuggets falling into peoples' pockets) and preaching of the prosperity gospel to people experienceing poverty and disease. The situation seems to be in sync with how Sigmund Freud describes religion in his book New Introductory Lectures on Psychoanalysis (1933). For Freud (1933), 'religion is an illusion and it derives its strength from the fact that it falls in with our instinctual desires'. In the case of Zimbabwe, there is much poverty, disease, unemployment, political tensions and hopelessness. People look up to religions such as Christianity for solutions to their problems and challenges. However, though religion seems to be an ideology that is beyond criticism, there are some theologians and philosophers who dedicate their work to questioning religious immunity from the rational scrutiny that the discourse enjoys. This led Voltaire to subject organized religion to rigorous analysis and criticism, because he did not believe any religion, let alone Christianity or the Church, to be the one and only interpreter of religious issues (Cliteur 2010). Voltaire sought to help believers to engage critically with all institutions of power, including the Church. The reasoning of empowerment cultivated critical discussion, freedom of thought and inquiry, freedom of conscience and freedom of speech. Voltaire favoured a scenario 
where people were freethinkers so as to deter villains from breaking the law and tyrants from exploiting their citizens. This called for the power of reason and a critique of faith or religion, so to empower citizens against unfortunate elements and tendencies associated with the clergy or institutions of religion or the Church. Voltaire propagated the use of reason. This attitude is particularly widespread in the West where no feature of religion has escaped scepticism and doubt. It is against this background that we interrogate the relationship that exists between faith and reason in an attempt to call for rational scrutiny of religious beliefs and practices in Zimbabwe. The emphasis on the use of only reason or only revelation should be avoided in Christians' daily life. This is not a situation of 'either/ or' but a 'both/ and' situation. Faith and reason can be differentiated, but never separated. Faith is an act of both the will and the intellect, whilst reason is an act of the intellect. One cannot talk of faith only, minus the operation of the mind or reason, especially if one wants to engage in the same faith. Failure to do that exposes people to manipulations as reported in media, e.g. poor lay people being ripped off of their hard-earned cash, or innocent women being raped by self-proclaimed prophets. Faith and reason must reciprocate each other as two sides of the same coin. Both faith and reason are essential to Christianity even as they function within their proper spheres.

\section{Conceptual Analysis}

In order to have a full appreciation of the discussion, we saw it fit to start off by analysing the concepts 'religion', 'faith' and 'reason'. The term 'religion' has been a bone of contention for religionists who do not agree on what the term means. Austin Cline (2019) notes that the fundamental problem with defining religion is that the definition is 'either too narrow or excludes many belief systems and practices which most agree are religions or (it is) too vague and ambiguous, suggesting that just about anything and everything is a religion'. The problem with a broad definition is that it ends up failing to exclude what is not religion. On the other hand, a narrow definition of religion ends up excluding non-traditional faiths, as well as minority religions that hinder the growth and development of religion. However, the best that religionists could offer is a working definition of religion. Thus, for the purposes of this article we adopt Hargrove's (1979) definition of religion as a human phenomenon that unites cultural, social, and personality systems into a meaningful whole. For Hargrove, religion's components generally include, 
(1) a community of believers who share;

(2) a common myth that interprets the abstractions of cultural values into historic reality;

(3) ritual behaviour, which makes possible personal participation, in

(4) a dimension of experience recognized as encompassing something more than everyday reality - the holy.

Just like religion, the word 'faith' is shrouded in several meanings. In some cases it can be used to depict hope, optimism or expectation. In religious circles, faith is founded upon belief in God. Hebrews 11:1, however, provides a biblical Christian definition of faith as 'the substance of things hoped for, the evidence of things not seen'. There are several or different understandings of the word faith in the Jewish Hebrew Bible. For instance, in we have the following in a selection of texts.

- In Habakkuk 2:4, faith is understood as denoting steadfastness, loyalty or faithfulness ${ }^{1}$.

- In Romans, faith is used to depict strong personal conviction ${ }^{2}$.

- In 1 Corinthians, it is used to speak of a spiritual gift ${ }^{3}$.

In addition to these, faith is also used to designate belief ${ }^{4}$; in other cases,

${ }^{1}$ And also 'So then they which be of faith are blessed with faithful Abraham' (Galatians 3:9); 'Let us hold fast the profession of our faith without wavering; (for he is faithful that promised)' (Hebrews 10:23); ' Fear none of those things which thou shalt suffer: behold, the devil shall cast some of you in prison, that ye may be tried; and ye shall have tribulation ten days: be thou faithful unto death, and will give thee a crown of life' (Revelations 2:10).

2 'And he that doubteth is damned if he eat, because he eateth not of faith: for whatsoever is not of faith is sin' (Romans 14:23).

3 'And though I have the gift of prophecy, and understand all mysteries, and all knowledge; and though I have all faith, so that I could remove mountains, and have no charity, I am nothing' (1 Corinthians 13:2).

${ }^{4}$ John 12:42 'Nevertheless, among the chief rulers also many believed on him; but because of the Pharisees they did not confess him, lest they should be put out of the synagogue'. See also Hebrews 11:6. 
trust $^{5}$ and obedience ${ }^{6}$. Holistically, faith involves many aspects of one's life.

Understood from a philosophical perspective, Collingwood (1968: 122) observes that faith is a religious attitude or habit of mind that,

accepts without criticism, pronounces without proving and acts without arguing. It knows nothing of analysis and classification, hypothesis and induction and syllogism. For the machinery of thought it has no use.

From Collingwood's definition of faith, it can be seen that faith is viewed as an uncritical disposition towards matters to do with divinity. Faith then strongly holds the view that the truth of religious propositions is indubitable. Different philosophers came up with different understandings of the word 'faith'. For instance, William James in his book, The Will to Believe and Other Essays (1896:1), gives a description of faith as our 'right to adopt a believing attitude in religious matters'. Thomas Aquinas observes that faith is 'an act of the intellect assenting to the truth at the command of the will' (1945). Whenever there is an engagement with faith claims, the intellect must also be summoned and involved in order to appreciate the truth claims at hand. For John Locke (1689:416), faith is an 'an assent to [a] proposition ...'. It is our conviction that faith is of paramount importance in religious circles and it is a necessary characteristic of mankind. For purposes of our article we will capitalize on Collingwood's definition that depicts the uncritical and irrational nature of faith. Pentecostal Churches' understanding of faith fits under Collingwood's definition where faith and reason are regarded as divorced. In most cases, reason is shunned and side-lined.

The term 'reason' also has its own problems, especially when used as synonym for common sense. Lionel Ruby (1960) in his text, Logic: An Introduction, formulated what has come to be known as the law of rationality. According to Ruby (1960),

5 'Let not your heart be troubled: ye believe in God, believe also in me' (John 14:1). See also Romans 14:17-20 and Luke 7.

6 'And the Lord spake unto Moses and Aaron, Because ye believed me not, to sanctify me in the eyes of the children of Israel, therefore ye shall not bring this congregation into the land which I have given them' (Numbers 20:12). See also, John 3:36; Romans 1:5 and Hebrews 10:39. 
Every person who is interested in logical thinking accepts what we shall call the 'law of rationality', which may be stated as follows: We ought to justify our conclusions by adequate evidence .... By 'adequate evidence' we mean evidence which is good and sufficient in terms of the kind of proof which is required. There are occasions when we require conclusive proof, as in mathematics, and there are occasions when it is sufficient to establish the probability of a given conclusion, as in weather prediction. But in all cases the evidence must be adequate to its purpose.

In this regard, reason is believed to depict a mental process known as inference whereby the mind apprehends logical connections between facts or between given premises and a conclusion. These premises and conclusion form what in logic is called an argument. The argument can either be arrived at deductively or inductively. In the former, the conclusion derives from the premises with logical necessity, whereas in the latter the conclusion follows with logical probability. Drawing from this then, reason should be taken to mean the ground, support or justification of an act or belief.

\section{The Philosophic Background to the Problem of Faith and Reason}

The relationship between faith and reason has seldom been tranquil or peaceful; rather, conflict and controversy appear at every turn. Serious religious thinkers as well as some philosophers have argued that faith and reason are not compatible at all and that their relationship is, and must be, that of mutual rejection and hostility. The question becomes, is religious belief rational? Or is faith an irrational activity? Or is it a rational one? Can rationality and faith connect? Can one be a rational believer? Hudson (1991) notes that, most religious traditions consider their teachings to be based on pronouncements from superhuman/ divine sources and thereby exempt from rational criticism. In some cases reason is declared to be finite, limited and even tainted, and therefore not competent to make judgements concerning the truth of what is divinely revealed. In light of this, it is the inspired writings of religious traditions, their scriptures or holy books that serve as the source of divine revelation and their adherents are often expected to just accept and believe the teachings derived from these writings unquestioningly. It is from this point of 
view that the source of religious truths ought to be revelation or faith. When philosophers and theologians begin to raise criticism to the uncritical acceptance of religious dogmas, they base their objection on the claim that reason has discovered some inconsistences in the doctrines themselves, or between religious knowledge claims derived by reason from other sources. This sets the stage for a feud between supporters of faith and advocates of reason.

To this effect, the debate on faith and reason saw the emergence of two schools of thought. On the one hand, there are those that believe that faith and reason are commensurable; that is, it is rational to believe in God. These are the views of such acclaimed philosophers as St Thomas Aquinas and Immanuel Kant, among others. In an attempt to reconcile faith and reason, Aquinas insisted that they are both gifts of God (faith and reason); therefore, they could not possibly be in conflict. Aquinas argued that there are many things that reason is competent to discover for itself, unaided by revelation, and it is clear that God intended us to use it for just that purpose. On the other hand, some things are beyond the powers of reason. Among these are things that humans need to know because they are essential ingredients in the practice of religion and for human salvation.

Aquinas further argued that, through reason we can know that God exists, because God has revealed himself to us through scriptures, prophets, the doctrine of the church and the incarnation. But there are certain things about God that reason finds unacceptable and cannot even understand; for example, that God is a Trinity or three persons in one, or that Christ is both fully human and fully divine (Hudson 1991). The scriptures were written in advanced Greek and Hebrew; a sign that the authors used their minds to engage people of their time. It is the same scriptures where languages such as Greek and Hebrew had to be used to communicate. The writers used the power of reason to communicate in an understandable way. The process took some decades or centuries to copied into the different languages, as in the case of Africa. All these processes involved the power of the mind. On the part of biblical writers, they reasoned with their audience in case of doctrinal misunderstandings or bringing the message home. Paul used reasoning in his ecclesiological, pneumatological, hermeneutical, theological and soteriological discourses. Paul used philosophical arguments to engage his audience, for example, Corinthians, Romans and Galatians, and he used reason to illustrate the power of faith. Aquinas wrapped up by indicating that God provided the overlap of faith and revelation for a good and deliberate purpose, that is, to make it possible for us 
to test the workings of reason as we develop more fully its use. What this means then is that, though Aquinas advocated a mutually inclusive relationship between faith and reason, his arguments implies that faith must have the final authority. Aquinas appreciated the marriage between reason and faith. However, the fact that he advocates for the superiority of faith over reason makes his views unattractive. For one critic, Aquinas placed the doctrine of the Trinity beyond the competence of reason and this is tantamount to exempting it from rational scrutiny. This is the trend today where people think issues of faith did not need reasoning or the participation of the mind.

From a rational perspective, the doctrine of the Trinity is a violation of the laws of logic, that is, the principle of non-contradiction, which states that it is impossible for the same thing to belong and not to belong to the same thing in the same respect at the same time. What this implies is that the 'same thing' that belongs must be one and the same thing; it must be the actual thing and not merely its linguistic expression. In support of Aquinas' views, John Calvin and Karl Barth asserted that a natural theology is inappropriate because it seeks to meet unbelief on its own. The Trinitarian discourse has remained elitist and difficult to understand for lay people, for example, to talk of God, the Son and the Holy Spirit as one and co-equal. Yet people find it heretical to pray by mentioning the Son first, the Holy Spirit and ending with the Father. Why the hierarchical order if they are one and co-equal? In this regard, faith is not against reason, but above and beyond it is its own proper domain. Faith must be reasonable to its beholders. Faith holders must be able to question as well as express their faith reasonably.

Kant pushed Aquinas' argument further and maintained complete harmony between faith and reason; that is, religious belief within the realm of reason alone. After Kant, many thinkers distinguished as well as separated faith from reason. Faith and reason were thought to occupy two entirely different spheres. Faith could be spoken of in terms of probability, mystical experience, supra-rationality, irrationality, being beyond knowledge and so on.

This leads us to the second school of thought which denies the assertion that faith and reason are commensurable. These views are represented by philosophers such as David Hume, Søren Kierkegaard, Karl Barth and John Calvin, among others. Peterson gives a clear biblical example of how the apostle Paul emphasizes the conflict between reason and faith. In Colossians $2: 8$, writers after Paul write, 'See that no one makes a prey of you by philosophy and empty deceit' (Peterson et al.). Further to this, the Early Church 
Father and writer, Tertullian, popularly asked, 'What has Athens to do with Jerusalem?' (Petersen et al. 1991). The implied answer is, 'Faith and philosophy have nothing in common; they are totally opposed', In line with this argument Pascal wrote, 'The heart has its reasons which reason does not know'. Pascal implied that some persons might have to take steps to dull their reasoning faculties in order to be able to believe. The quest for knowledge, and the desire for certainty is two of the concerns most characteristic of Western philosophy. This goal of philosophy is clearly demonstrated by Rene Descartes in his five rules for the direction of the mind. He sets forth that we should refuse to believe anything that is subject to doubt. Building on this idea, some philosophers have argued that human beings have no right to extend belief beyond the available evidence.

Those who stretched the argument further hold that reason is the sole source of knowledge. This is the view that rationalists such as Plato, Descartes, Spinoza and Leibniz championed. Plato gave the allegory of the chariot. In the Phaedrus, Plato, through Socrates, has it that,

The chariot is pulled by two winged horses, one mortal and the other immortal. The mortal horse is deformed and obstinate. Plato describes the horse as a 'crooked lumbering animal, put together anyhow ... of a dark color, with grey eyes and blood-red complexion; the mate of insolence and pride, shag-eared and deaf, hardly yielding to whip and spur'. The immortal horse, on the other hand, is noble and game, 'upright and cleanly made ... his color is white, and his eyes dark; he is a lover of honor and modesty and temperance, and the follower of true glory; he needs no touch of the whip, but is guided by word and admonition only'. In the driver's seat is the charioteer, tasked with reining in these disparate steeds, guiding and harnessing them to propel the vehicle with strength and efficiency. The charioteer's destination? The ridge of heaven, beyond which he may behold the Forms: essences of things like Beauty, Wisdom, Courage, Justice, Goodness - everlasting Truth and absolute Knowledge. These essences nourish the horses' wings, keeping the chariot in flight (McKay \& McKay 2013).

In the allegory, the Charioteer represents man's reason, the dark horse his appetite and the white horse his spirit. Each element has its own motivations 
and desires. Thus, reason seeks truth and knowledge, and appetites seek drinks, sex, and material wealth, and the spirit seeks glory, honour and recognition (McKay and McKay 2013). To this effect, Plato ranked his three parts of the soul with reason being at the apex followed by the spirit and the appetites. Being at the apex, reason's duty is then to control the spirited part and the appetites. Having looked at how reason is viewed in philosophy, we now turn our attention to how reason manifests in the New Testament?

\section{The Celebration of the Power of Reason and Faith in the New Testament}

Those who argue that faith has nothing to do with reason and vice versa miss the point. Some of the scriptures in the Holy Bible show that there is room for 'rational belief', For instance, Isaiah 41: $21^{7}$ demonstrates the test between one true God and the false gods. The test obviously involved reasoning on the part of the believers. Deuteronomy 13 also makes the same call by commanding the Israelites to practise sound judgment by thoroughly testing the teachings of their leaders. There are a number of Biblical texts that celebrate reason as important to faith (Job 2: 11-12, 36; Proverbs 5: 23, 23: 7; 1 Chronicles 10: 1112; Isaiah 1: 18-19, 29: 14, 43: 26, 55: 8-9; 1 Peter 1: 13, 3: 15; Romans 2: 1418, 8: 5-7, 12: 2; Acts 17: 22-23, 17: 2-4, 18: 4; 1 Corinthians 13: 11; 1 Tim 2: $3-4$; Mt $4: 17)$. Jesus is often quoted out of context that he commanded that 'Judge not, or you too will be judged' (Matthew 7: 15-20). Yet Jesus exhorts people to judge false prophets and teachers whose teachings and behaviour lead people astray (Croteau 2015). The evidence of marriage between faith and reason can also be found in 1 Thessalonians 5: $21^{8}$. Paul urges Christians to prove or test all things by seeking evidence or proof for everything. Thus, the phrase 'prove everything' extends to even question-ing the so-called miracle workers or miracles. According to W.K. Clifford (in Cliteur 2010),

No ideology, no book, no religion, no cultural practice may be exempt from criticism. That implies that, on the basis of 'test everything; hold

\footnotetext{
7 'Produce your cause, Saith the Lord; bring forth your strong reasons, saith the King of Jacob' (Isaiah 41:21).

8 'Prove all things; hold fast that which is good' (1 Thessalonians 5:21). See also Romans 12:2; 2 Corinthians 8:8.
} 
fast to what is good' (1 Thessalonians 5: 21), the Bible itself has to be tested. Some passages are good whilst some are bad. The testing that 1 Thessalonians 5: 21 encourages us to do have also implications for the Holy Spirit itself.

The manifestation of God, Jesus and the Holy Spirit in Churches has to be put to test. If the Holy Scriptures can be tested, this does not exempt preachers of the gospel, their doctrines and their lifestyle. All convictions, beliefs and ideas must be put to test for the good of society. No-one is entitled to privileges merely on the grounds that they are votaries of the divine or certain powers, hence exempt from being criticized. There are many occasions when the members of the clergy are fond of using words such as 'I have a word from the Lord or God told that'. As a result, people find it very difficult to disagree or engage in any discussion with someone who claims to have received direct commands from God. On some occasions, the claims have turned out to be false, selfish or manipulative (Chan 2009). Paul calls people to use the power of the mind by testing all things at their disposal. 1 Thessalonians 5: 21 exhorts Christians to examine carefully and critically everything one hears and sees. Some critics would like to argue that Paul implied testing everything to do with prophecies. Yet it's not always the case that when people meet it's all about prophecies. Christian gatherings involve a lot of teachings and declarations that are manipulative by nature though not prophetic. Testing for Paul possibly implied whenever spiritual instruction was involved (Chan 2009). Pink (2012) argues that, on many occasions the Christ of many pulpits is radically different from the Christ of God, because of preachers who change the figment of their own imagination with the name of 'Christ'. Many innocent Christians or laypersons get deceived into supposing that it is the Christ of the Scriptures who is set before them. In order for one to be able to discern between false and truth, there is need to evoke the powers of reason. Faith alone would not help matters in a scenario where there is a thin line between false and orthodox teachings.

In Acts 17: $11^{9}$, reason was given an honorary position. The book of 1 Peter 3: 1 also sets forth the justification of a rational belief in God. The writer puts it upon every Christian to be in a position to give reason or justification

9 'These were more noble than those in Thessalonica, in that they received the word with all readiness of mind, and searched the scriptures daily, whether those things were so' (Acts 17: 11). 
for the hope they have in God, Christ, Word of God and the Church and so on ${ }^{10}$. Every belief for the writer of 1 Peter needs to be reasonable and justifiable.

From these scriptures it can be demonstrated beyond any reasonable doubt that reason and faith need each other in the development of an informed believer. It is our conviction that the most critical issues facing today's Christians is the extensive desertion of rational belief. Faith is an act or power of a well- informed mind to make its own choices or decisions. In other words, it is a nexus between the will and the intellect, not one in the absence of the other. Thus, on the one hand, knowledge in the absence of devotion is tantamount to disbelief and on the other hand, devotion in the absence of knowledge is tantamount to irrationality. In short, faith and reason ought to work as checks and balances of each other in order to avoid some of the issues facing the modern church.

\section{Modern Pentecostal Churches, Teachings, Faith, Miracles and the Shunning of Reason}

Pentecostal teachings on curses and blessings call for analysis especially in the case of Africa in general and Zimbabwe in particular. African believers have been exposed to strange demands with the hope of being blessed or remembered by God. There have been several cases that have been recorded in both print and electronic media of pastors and prophets calling upon followers to eat grass (Manuel-Logan) or drink diesel or sewage or eat snakes or dog meat (Mitchley \& Schatz 2015) or throw away life-saving drugs if they are to be remembered or experience the power of God. One of the prophets, Rufus Phala, allegedly gave his members Jik, a household bleach, to drink as a sign of faith during a church service (cf. Mitchley \& Schatz 2018). Six members died after drinking Jik. While this happens, they are reminded that, things of faith do not need any reasoning. On most occasions, innocent victims have been abused at the hands of gullible prophets. Some have been sexually and financially abused in the name of God. What is surprising is that people do not want to look at other factors that cause poverty in Africa.

10 'But sanctify the Lord in your hearts: and be ready always to give an answer to every man that asketh you a reason of the hope that is in you ...' (1 Peter 3:15). 
Africa has passed through a number of sad episodes such as slavery and colonialism. The two episodes left a dent on the lives of Africans and the dent will affect Africa for generations to come. Zimbabwe is not an exception when it comes to how colonialism has ripped the lives of the majority of the Zimbabwean rural folk apart. Colonization is responsible for most of the poverty, socio-economic classes and disease witnessed and experienced in Africa. African indigenes lost most of the arable land. There are several factors that determine or establish peoples' understanding of blessings and curses. For Vengeyi (2011: 223 - 237),

Colonization is responsible for the poverty that many African states are going through. Although, Africa is politically independent, it is still economically colonized. Land was and remains the means of production for many indigenous Africans. As such, land alienation was in effect economic alienation. Until the year $2000,70 \%$ of arable land in Zimbabwe was owned by 4500 whites while more than 13 million were landless. Whites had either inherited the land from their ancestors or had bought from their parents and friends. As such, to claim that Africans are poor as a result of lying, hence sinful is not only unfair but also a belief in lies.

Land loss has been the talk in Africa and most African states have tried to address inequalities. Colonization resulted in the religio-cultural, political and social domination of the indigenes (Zimunya \& Gwara 2013). Christianity, on the other hand, legitimized the oppression of the local people. Missionaries were handmaidens to the colonisation plot. Africans were made to ignore earthly material possessions and focus on going to heaven (Lk 6:20; 18:12; Mt $6: 19-20,6: 24 ; 8: 20)$. Biblical texts were quoted out of context by missionaries. Most of the services offered by missionaries to Africans were meant to entrap Africans into servitude and poverty. Missionary education similarly created a class of Africans who served as efficient instruments in the establishment of colonial rule. European colonisation of Africa would have been difficult without missionary assistance. Africans have found it difficult to recover from such a sad history.

It is sad to realize that Pentecostal preachers choose to ignore the sad history of colonialism and its impact on the lives of indigenes. In fact, Pentecostal preachers have continued to make the same call that bastardises 
Africans as hopeless and disobedient sinners who are under the cloud of generational curses; hence the reason why the majority of Africans are poor. Prosperity gospel legitimises the unequalled access to resources as ordained by God through curses and blessings. People are made to accept the unacceptable. It is the gullible believers who use their reasoning power to question such teachings. Vengeyi (2011:107) shows how the biblical Amos dismissed the doctrine of prosperity by looking at the concrete historical, legal and economic policies that were skewed against the poor. For Amos, God had nothing to do with the poverty of the majority poor, since their condition of poverty results from man-made policies. It is the same call that we make in this article, namely that any discourse on poverty and prosperity will not help address the problems faced by Africans if one does not look at the historical-colonial and Western world-pushed economic policies of the International Monetary Fund and the World Bank on Africa. The two institutions have forced third-world economies to open their economies to Western penetration and increase the export of primary goods to wealthy nations to multiply profits for Western multinational corporations while exposing African nations to horrendous levels of poverty, unemployment, malnutrition, economic decline and illiteracy (Ismi 2004). However, there are other factors that impoverish Africans, for example, corruption, poorly planned policies and contested elections that sometimes result in civil war or political violence and nepotism. In this case, poetry has nothing to do with God but men. Any talk about demons being the source of poverty for most of the Africans is a sad and contemptuous attitude towards Africans who have been victims of other races.

The multiple challenges cause Africans to find solace and hope in religions such as Christianity. The recipients of prosperity gospels, for unknown reasons, fail to realize that some of their challenges have nothing to do with the spiritual realm, but the human or physical realm. People must be careful as some of the teachings are heretical and not Christian. On the other hand, it could be possible that the Pentecostal prophets and pastors believe what they teach because they read all biblical texts at face or literal level. The understanding is that the Bible must not be academically engaged hence the usual call to 'suspend all reasoning'. According to Chimuka, (2013) some black Pentecostal founders lack sound theological training. A number of Pentecostal pastors have questionable academic qualifications which make it very difficult for them to engage with the same Bible they profess to know. The number of miracles that have been experienced in some of the Pentecostal 
Churches have helped draw people to their churches. It is only the gullible that have questioned or queried some of the Pentecostal doctrines and miracles.

According to Vengeyi (2013), critics suspect that some clergymen such as Makandiwa and Angel could be playing African magic acquired from either Ghana or Nigeria. Critics' concerns were confirmed by Sekuru Elisha Matanga, a traditional healer, who claims to be the force behind countless miracles performed by several prominent prophets in the country by saying,

The prophets' success is due to my powers and some of these prophets are involved in satanic practices. What you have to understand is that nowadays the church is now a business and most church leaders mainly prophets are desperate for power and money for them to draw many people. Most of these Zimbabwean prophets who are making a lot of noise in the country are my clients, not all of them but most of them. I cannot reveal their names because my service is confidential to me and my clients. We strengthen them and we give them powers to perform. What amazes you in churches and to some we even host traditional ceremonies for them here. Those whom I have imparted my powers operate with a good spirit because my powers are linked to ancestral spirits but there are some who have gone to the extent of getting satanic powers. They kill to attain miracle power; some of them make covenants which are costly for their lives. I want all Christians to be careful on who shepherds them spiritually.

Critics are justified to argue that Zimbabwean prophets and diviners or $n$ 'angas suspiciously operate at the same level. For Matanga, it is only the gullible Christians who will be able to survive the machinations of some gullible prophets and Church leaders who have turned the Church into their business projects. Critics are justified being sceptical and suspicious of spiritual foul play. Some prophets have simply chosen to vacillate between the traditional African realm and Christianity when addressing African problems. What is interesting is that most of the prophetic movements are domiciled in towns and cities where there are opportunities. As a result, the focus is not on salvation, but on materialism and personal wealth that promote individualism, as opposed to serving others. In the end, it is the Pentecostal prophets and pastors who benefit. For Zimunya and Gwara (2013), generous giving by members to founders has fuelled their lavish lifestyles that contrast with the poverty of the 
general members.

Proponents of prosperity theology have been regarded as deeply interested in their own prosperity at the expense of members of the churches (Chitando 2013). They avoid rural areas where the majority of people remain poverty stricken, thereby making the gospel of prosperity relevant and necessary in empowering the people against poverty and disease. If poverty for prosperity gospel preachers has to do with sin, lack of faith and evil spirits; then it implies that rural areas are under siege from the devil or Satan; hence the need for prosperity gospel preachers to pitch their tents in rural areas. If cities and towns experience frustration, disappointments, betrayals, false promises by the government, lack of opportunities, uninhabitable shanty houses, unemployment, malnutrition, violence, and poverty, and diseases such as cholera, typhoid and lack of medication; the scenario will be dire or worse in rural areas. Therefore, it is not surprising that, people flock to cities and towns in search of opportunities. Mayrargue (2008) rightly notes that Pentecostal Christianity has attracted Africans as a result of the problems they face. And Pentecostal Christianity, on the other hand, claims to solve all daily life and existential problems. Kugler notes that poverty is one of the most urgent problems, which cannot be ignored, since it is a challenge of peace and justice (Kügler 2013). In the case of Zimbabwe, the Pentecostal claim to solve all problems targets people (youth, women and persons with disabilities) who are faced with the decreasing quality of life, feelings of isolation and loss of traditional points of reference (Mayrargue 2008). It is understandable that, when miracles get stage managed, people flock there in the hope of being helped. The decreasing quality of life has left the world wondering as to how to deal with HIV and the AIDS pandemic where the virus has remained elusive in terms of killing it. ARVs have helped to minimize the pain and loss of loved ones. It was the power of the mind and faith in God through the drugs that has helped prolong the lives of those living with the HIV virus. Of late, Prophet Magaya spoke to his Church congregants and claimed to have found cure for the HIV virus and cancer when he said,

I have been praying for it, and I have been concentrating on it, but I want to assure you, the world may deny it, but they will eventually agree, because you cannot fight with facts and win. Facts are facts. I have seen the hand of the Lord healing his people. I have seen testimonies and I have prayed for people. But while praying, I asked 
God to lead me to something that can help many. He showed me a tree, he showed me my counterparts in India. We have tested it and found out that it works. I can stand in front of you as a man of God and say I have found a cure for Aids. We have tested on people living with HIV and these people have gone negative. If a person takes the medication, made from an Aguma plant, within 14 days, his CD4 count will have gone up by $200 \%$, suppressing the virus before it eventually disappears. Yes, you have heard me correctly, we have found the cure (Daily News 31 October 2018).

Magaya's claims were met with mixed reactions from a cross-section of people. As for his congregants, they ululated, sang and danced in appreciation of the man of God for such developments that had been elusive to world experts and scientists who had accepted that no cure had been found. The jubilation also confirmed that a number of Magaya's congregants possibly lived with the virus and that they were possibly taking anti-retroviral drugs. Zimbabwe is believed to have around 1,4 million people living with the HIV virus and 1,2 million are on ARVs. Magaya went further and claimed that,

When I approached the government, their response made me feel that they were ready to support us. Government will carry out its own research and is summoning a local research board to bring in people who are HIV positive and take statistics on people taking Aguma. They will test it for any threats to health, its efficacy and side effects among many other things and have the final say. The government was set to announce the first public results on Aguma after 14 days. The herb had undergone the appropriate registration as a supplement in Zimbabwe. We have also approached the World Health Organisation. We wrote to the World Health Organisation (WHO) and they said they would work hand-in-hand with government rather than individual-to-individual (Daily News 31 October 2018).

Magaya's claims were quickly rubbished by the Zimbabwean government and the Medicines Control Authority of Zimbabwe (MCAZ). The Government Health and Child Care, Deputy Minister, John Mangwiro, warned Magaya that he risked facing the full wrath of the law if he goes ahead and sells Aguma. Mangwiro warned that, 
If he goes ahead and sells the drug ... we will stick to the Constitution of the country and the law in terms of drugs and sales. The law will definitely take its course if he breaches it as Magaya's herbal medicine was not registered, people should not buy it. I don't think people are going to be foolish enough to buy the drug on Saturday. From our research, we gather that the medicine costs $\$ 1000$.

The Minister of Information, Monica Mutsvanga, also weighed and dismissed Magaya's claims by encouraging all clients on treatment for HIV and Aids to continue with their prescribed medication, as any form of discontinuation or switch made without the guidance of medical professionals would lead to adverse consequences to their health status (Herald 30 October 2018). World authorities and organizations working with people living with HIV have for long accused faith healers encouraging people to dump medication on false claims that they had been miraculously healed. On most occasions the publicity stunt sought to market the prophets' healing powers at the expense of peoples' lives. Mangwiro, Deputy Minister of Health, felt people who would believe Magaya without putting to test his claims as foolish. He called upon people to question statements said on pulpits by pastors, lest their lives would be risked by accepting the unacceptable, especially coming from people who had no idea how research or medical tests are done, as they had never been trained as medical doctors.

\section{Conclusion}

The current developments in Christianity call for the power of both faith and reason to guard against abuses that emanate from the Church, and its pastors and prophets. The article sought to show that reason plays an important role in empowering both the laity and the clergy against teachings that mislead and divide communities on the basis of the rich and poor, or curses versus blessed.

\section{References}

Chan, F. 2009. Forgotten God: Reversing our Tragic Neglect of the Holy Spirit. USA: David C. Cook Ltd.

Chimuka, T.A. 2013. Reflections on the Morality of some Prophetic Acts in 
Zimbabwe's Pentecostal Movements. In Chitando, E., M.R. Gunda \& J. Kügler (eds.): Prophets, Profits and the Bible in Zimbabwe. Bamberg: University of Bamberg.

Chirisa, S. 2018. Prophet Makes Congregants Drink Jik in Church.

https://iharare.com/prophet-makes-congregants-drink-jik/

Chitando, E. 2013. Prophets, Profits and Protests: Prosperity Theology and Zimbabwean Gospel Music. In Chitando, E. M.R. Gunda \& J. Kügler (eds.): Prophets, Profits and the Bible in Zimbabwe. Bamberg: University of Bamberg.

Cline, A. 2019. What is Religion? Defining the Characteristics of Religion. Available at:

https://www.learnreligions.com/defining-the-characteristics-of-religion250679

Cliteur, P. 2010. The Secular Outlook in Defense of Moral and Political Secularism. Hoboken, NJ: John Wiley and Sons Ltd Publishers. https://doi.org/10.1002/9781444325324

Collingwood, R.G. 1968. Faith and Reason: Essays in the Philosophy of Religion. Rubinoff, L. (ed.). Chicago: Quadrangle Books.

Croteau, D.A. 2015. Urban Legends of the New Testament: 40 Common Misconceptions. Nashville: B. and H. Publishing Group.

Daily News 2018. Prophet Magaya Faces Arrest. Daily News 31 October 2018. Freud, S. 1933. New Introductory Lectures on Psychoanalysis. Oxford: England Norton and Co.

Global Black History 2019. The Role Played by Missionaries in the Colonisation of Africa.

https://www.lensshift.org/library/role-of-missionaries-in-colonizationof-africans (Accessed on 25 and 28 October 2019.)

Hargrove, B. 1979. The Sociology of Religion: Classical and Contemporary Approaches. $2^{\text {nd }}$ Edition. Illinois: Harlon Davisson, Inc.

Herald 2018. Government Dismisses Magaya's Claims. 30 October 2018.

Hudson, Y. 1991. The Philosophy of Religion. Mountain View: Mayfield Publishing Company.

iHarare 2014. Prominent Zimbabwe Prophet Makes Congregants Eat Grass, Mud for Deliverance. https://iharare.com/prominent-zim-prophet-makescongregants-eat-grass-mud-for-deliverance/

James, W. 1896. The Will to Believe and Other Essays. New York: Longmans, Green \& Co. 
Ismi, A. 2004. Impoverishing a Continent: The World Bank and the International Monetary Fund in Africa.

https://www.google.com/search?ei=uBv

WW73jFeXwgAaUiZ3YCw\&q=International+Monetary+Fund+and+th $\underline{\mathrm{e}+}$

World+Bank+impoverishes+frica\&oq=International+Monetary+Fund+a nd+the+World+Bank+impoverishes+frica\&gs_l=psyab.3...2474.9151.0.9398.19.18.0.0.0.0.594.2066.3-

3j1j1.5.0...0...1c.1.64.psy-

ab..14.4.1462...0i22i30k1j33i21k1.0.2H80CwCadng

(Accessed on 28 October 2018.) https://doi.org/10.1144/geosci-28-9

Kügler, J. 2013. People with a Future: Jesus' Teaching on Poverty and the Role of Poor People in Christian Churches Today. In Chitando, E., M.R. Gunda \& J. Kügler (eds.): Prophets, Profits and the Bible in Zimbabwe. Bamberg: University of Bamberg.

Locke, J. [1689] 1894. An Essay Concerning Human Understanding. Volume II. Fraser, A.C. (ed.). Oxford: Clarendon Press.

Mayrargue, C. 2008. The Paradoxes of Pentecostalism in Sub-Saharan Africa. IFRI.

Mbiti, J. 1969. African Religions and Philosophy. London: Heinemann. McKay, B. \& K. McKay 2013. A Man's Life: On Manhood, On Virtue, Personal Development. Available at: https://www.artofmanliness.com

Mitchley, A. \& C. Schatz 2014. 'Snake Pastor' Feeds Dog Meat to Congregants for Communion.

https://www.news24.com/SouthAfrica/News/snake-pastor-feeds-dogmeat-to-congregants-for-communion-20181016 (Accessed on 28 October 2018.)

Nehandara Radio 2014. Prophet Orders Congregation to Eat Live Snake, Tells them it will Taste like Chocolate.

http://nehandaradio.com/2015/07/14/prophet-orders-congregation-to-eatlive-snake-tells-them-it-will-taste-like-chocolate/

Peterson, M., W. Hasker, B. Reichenbach \& D. Basinger (eds.). 1991. Reason and Religious Belief: An Introduction to Philosophy of Religion. New York: Oxford University Press.

Pink, A.W. 2012. An Exposition of First John. Prisbrary Publishing. Reilly, J. 2014. South African Pastor Makes Congregation Eat Grass to be Closer to God. https://www.dailymail.co.uk/news/article-2537053/Lawn- 
Christians-South-African-preacher-makes-congregation-eat-GRASScloser-God.html (Accessed on 28 October 2018.)

Ruby, L. 1960. Logic: An Introduction. Chicago: J.B. Lippincott.

St. Thomas Aquinas [c. 1269] 1945. Summa Theologiae, II (Qu. 4, Art. 5). In Pegis, A.C. (ed.): Basic Writings of St. Thomas Aquinas. Volume 2. New York: Random House.

The Nigerian Voice 2018. 6 Dead as Prophet Makes Congregants drink Jik in

Church. https://www.thenigerianvoice.com/news/270602/marchant-ofdeath-6-dead-as-prophet-makes-congregants-drink.html (Accessed on 28 October 2018.)

Vengeyi, O. 2011. 'Zimbabwean Poverty is Man-Made': Demystifying

Poverty by Appealing to the Prophetic Book of Amos. Scriptura 107: 223-

237. https://doi.org/10.7833/107-0-138

Vengeyi, O. 2013. Zimbabwean Pentecostal Prophets: Rekindling the True and

False Prophecy Debate. In Chitando, E., M.R. Gunda \& J. Kügler (eds.):

Prophets, Profits and the Bible in Zimbabwe. Bamberg: University of

Bamberg, 2013

WHO Trashes Magaya HIV Cure Claim. The Chronicle 01 November 2018.

Youtube 2018. Prophet Magaya Claims HIV \& Cancer Cure - 28 October 2018

Full Video.

https://www.youtube.com/watch?v=Lm7BuuACUvI

(Accessed on 28 October 2018.)

Youtube 2018. Government Speaks on Prophet Magaya's HIV Cure Claims.

https://www.youtube.com/watch?v=iEbDrROLUi0

(Accessed on 28 October 2018.)

ZIM Doctors 2018. Prophet Magaya must Stop!

https://allafrica.com/stories/201810290299.html

Zimunya, C.T. \& J. Gwara 2013. Pentecostalism, Prophets and the Distressing Zimbabwean Milieu. In Chitando, E., M.R. Gunda \& J. Kügler (eds.): Prophets, Profits and the Bible in Zimbabwe. Bamberg: University of Bamberg.

Dr. Joyline Gwara Department of Philosophy, Ethics and Religion University of Zimbabwe Harare joyandjay71@gmail.com 
Impediments to Quality Education in Nigerian Tertiary Institutions

Prof. Francis Machingura Biblical Studies Curriculum and Arts Education Department Faculty of Education, and Acting Director of University of Zimbabwe Post-Graduate Studies University of Zimbabwe fmachingura@yahoo.com 